\title{
AN ANALYTICAL INDEX
}

TO THE

\section{American Journal of International Law AND SUPPLEMENTS}

Volumes 1 to 14 (1907-1920)

AND THE

\section{PROCEEDINGS}

OF THE

\section{American Society of International Law} ...

$$
\text { 1907-1920 }
$$

PRTPARED BY

GEORGE A. FINCH

Secretary of the Board of Editors of the American Journal of International Law

PUBLISHED BY THE SOCIETY

2 Jackson Place

WASHINGTON, D.C.

1021 
Copyright, 1921, BY THE American Society of International Law

TAD ROMTORD PREBS CONCORD, NEW HAMPAHIRE 